\title{
Health-care workers' (HCWs') compliance with recommendations of WHO regarding the seasonal influenza vaccination
}

\section{Przestrzeganie przez personel medyczny zaleceń Światowej Organizacji Zdrowia dotyczących szczepienia przeciw grypie}

\author{
Agata Maria Kawalec ${ }^{1, A-D \oplus}$, Anna Maria Kawalec ${ }^{1, A-D \odot}$ \\ ${ }^{1}$ Medical University, Wrocław, Poland \\ A - Research concept and design, B - Collection and/or assembly of data, C - Data analysis and interpretation, \\ $D$ - Writing the article, $E$ - Critical revision of the article, $F$ - Final approval of article
}

Kawalec AM, Kawalec AM. Health-care workers' (HCWs') compliance with recommendations of WHO regarding the seasonal influenza vaccination. Med Srod. 2020; 23(1-4): 5-8. doi: 10.26444/ms/139579

\begin{abstract}
Objective. The aim of the study was to characterize healthcare workers' (HCWs) compliance with recommendations of the WHO regarding the seasonal influenza vaccination.

Materials and method. An anonymous questionnaire was used among $121 \mathrm{HCW}$ in hospitals in Wrocław, south-west Poland. The study was approved by the Bioethics Committee at Wroclaw Medical University.

Results. The rate of influenza vaccination in the research group during the season 2015-2016 was 9.9\%, and during the season 2016-2017-13.9\%. HCWs who had been vaccinated at least once were asked about the reasons for their decision to be vaccinated. The most frequently chosen answers were contact with patients and to avoid flu-related complications (respectively, 23\% and 21\% of answers). Both concern for one's health and chronic diseases, as well as subjective assessment of low immunity, were indicated in $25 \%$ of respondents as reasons for influenza vaccination. The main reasons for non-vaccination were lack of time $(41 \%)$, costs $(21 \%)$ and the subjective assessment that flu immunization is either unnecessary or ineffective (22\%). Regarding knowledge about vaccination, $91 \%$ of HCWs recommended having a flu vaccination each season annually. About $18 \%$ of HCWs admitted that they did not know the recommendations. The main sources of knowledge about influenza and vaccination against seasonal influenza were classes during the course of studies (26\%), the Internet (23\%), and information from doctors (14\%). About $53 \%$ of HCWs admitted that they had an influenza-like infection in the previous year, and $53 \%$ of them had contact with patients while having influenza-like symptoms.
\end{abstract}

Conclusions. Despite rather good knowledge about recommendations, HCWs did not have the vaccinations. Attention should be paid to the role of vaccination in the prevention of the spread of the disease and its complications.

\section{Key words}

health promotion, infection prevention, health-care workers, vaccination, seasonal influenza

\section{Streszczenie}

Cel pracy. Celem pracy było scharakteryzowanie przestrzegania przez pracowników służby zdrowia zaleceń Światowej Organizacji Zdrowia (WHO) dotyczących szczepień przeciw grypie sezonowej.

Materiał i metody. Anonimowa ankieta została przeprowadzona wśród 121 pracowników opieki zdrowotnej z wrocławskich szpitali i uzyskała pozytywną opinię Komisji Bioetycznej Uniwersytetu Medycznego we Wrocławiu nr 405/2017.

Wyniki.Zaszczepionych przeciw grypie w sezonie 2015/2016 było 9,9\%, a w sezonie 2016/2017 - 13,9\% badanych. Pracownicy, którzy zostali zaszczepieni przynajmniej raz, zostali zapytani o powody podjęcia decyzji o szczepieniu. Najczęściej wybieranymi odpowiedziami był kontakt z chorymi i unikanie powikłań związanych z grypą (odpowiednio 23\% i 21\% odpowiedzi). Troskę o zdrowie, choroby przewlekłe, subiektywną ocenę niskiej odporności jako przyczyny szczepienia wskazano w $25 \%$ odpowiedzi. Główne powody nieszczepienia to: brak czasu (41\%), koszt (21\%) oraz subiektywna ocena, że szczepienie przeciw grypie jest niepotrzebne lub nieskuteczne (22\%). Analizując wiedzę na temat szczepień, stwierdzono, że $91 \%$ pracowników medycznych ma wiedzę, że szczepienie przeciw grypie zaleca się corocznie, w każdym sezonie. Około $18 \%$ pracowników ochrony zdrowia przyznało, że nie wie, jakie są zalecenia. Głównymi źródłami wiedzy na temat grypy i szczepień przeciw grypie były zajęcia w trakcie studiów (26\%), Internet (23\%), informacje od lekarzy (14\%). Około 53\% pracowników medycznych przyznało, że w poprzednim roku chorowało na infekcje grypopodobne, a 53\% z nich w czasie gdy wykazywali objawy infekcji grypopodobnej, miało kontakt z pacjentami.

Wnioski. Mimo dość dobrej znajomości zaleceń dotyczących szczepień przeciwko grypie pracownicy ochrony zdrowia nie szczepią się przeciw grypie sezonowej. Należy zwrócić uwagę na rolę szczepień w zapobieganiu rozprzestrzeniania się tej choroby i jej powikłaniom.

\section{Słowa kluczowe}

promocja zdrowia, prewencja zakażeń, pracownicy medyczni, szczepienia, grypa sezonowa 


\section{INTRODUCTION}

In facing the problem of health promotion and prevention in occupational health systems in Europe, it must be noted that the quality of both can be improved, and it would be beneficial to underline the role of vaccination in occupational health. An interesting aspect is the compliance of health-care workers (HCWs) with the recommendations of the World Health Organization (WHO) regarding seasonal influenza vaccination. HCWs are at risk of occupational exposure to influenza due to their contact with patients. They may also act as vectors for nosocomial transmission to individuals at high-risk for flu-related complications. Despite many recommendations, the vaccination coverage among medical personnel remains low [1].

According to the Programme for Immunization in Poland, the influenza vaccine has been recommended since 1994 and everyone from the age of 6 months should have a flu vaccination every epidemiological season $[2,3]$. These recommendations are unanimous with those provided by the WHO or Centers for Disease Control and Prevention (CDC) in the USA. There are two main groups of recommendations - clinical or individual, and epidemiological. For epidemiological reasons, medical professionals are those of particular interest, not only because the risk for influenza infection is estimated to be about 6 times higher among medical personnel compared to the general population (59\% vs. $10 \%)$, but also because medical professionals can facilitate the transmission of influenza viruses to patients, which are very often individuals at high risk for influenzarelated complications [4]. Although since 1981 the CDC has recommended flu vaccination for all medical professionals, the vaccination rate among HCWs of different professions remains low [5]. In Poland, the vaccination rate among medical staff was estimated to be at 6\% [6], while in the general population it was about $3.4 \%$ in the $2015-2016$ seasons [7]. In accordance with the definition provided by CDC, HCWs include 'physicians, nurses, emergency medical personnel, dental professionals and students, medical and nursing students, laboratory technicians, pharmacists, hospital volunteers and administrative staff' [8].

\section{OBJECTIVE}

The aim of the study was to characterize the compliance of HCWs with the recommendations of the WHO regarding the seasonal influenza vaccination.

\section{MATERIALS AND METHOD}

A pilot study was conducted among 121 health-care workers (HCWs) who have direct contact with patients during work in hospitals in Wrocław, south-west Poland. Participation in the study was voluntary. Most of the HCWs were female (81\%), mean age -21.1 years ( \pm 1.43 years). Participation in the study was voluntary. The method used during the research was an anonymous questionnaire that focused on influenza vaccination in the 2015-2016 and 2016-2017 seasons, as well as reasons for being vaccinated or not, and knowledge about recommendations for influenza vaccination for healthcare workers and health-care students. Questionnaire also included questions about how often one should get vaccinated, and the main sources of knowledge.

The study was approved by Bioethics Committee at Wrocław Medical University (Approval No. 405/2017).

\section{RESULTS}

In general, the influenza vaccination rate in the research group during the 2015-2016 seasons was $9.9 \%$, and during the 2016-2017 season - 13.9\%. HCWs who had been vaccinated at least once (in 2015-2016 and/or 2016-2017 seasons) were asked about the reasons for their decision to be vaccinated (multiple choice question). The most frequently chosen answers were contact with patients and to avoid flu-related complications (respectively, $23 \%$ and $21 \%$ of answers). Both concern for one's health and chronic diseases (or subjective assessment of low immunity), were indicated by $25 \%$ of respondents as reasons for influenza vaccination; however, only 2 respondents admitted that they were vaccinated in accordance with a chronic disease (autoimmune hepatitis and ankylosing spondylitis). The main reasons for non-vaccination were lack of time (41\%), costs (21\%), and subjective assessment that flu immunization is either unnecessary or ineffective, which together were indicated in $22 \%$. Regarding knowledge about vaccination, $91 \%$ of HCWs indicated that having a flu vaccination annually, each season, is recommended. However, $2 \%$ confirmed that they do not know the correct answer. 79\% of HCWs knew the recommendations in the area of influenza vaccination, about $18 \%$ of HCWs admitted that they did not know what the recommendations are. In general, the main sources of knowledge about influenza and vaccination against seasonal influenza were classes during the course of studies (26\%), the Internet (23\%), and information from doctors (general practitioners $-10 \%$ or specialists $-4 \%$ ). About $53 \%$ of $\mathrm{HCWs}$ admitted that they had had an influenza-like infections in the previous year (self-reported subjective assessment), and 53\% of them had contact with patients while having influenzalike symptoms.

\section{DISCUSSION}

Although acquaintance with the annual seasonal influenza recommendations for HCWs, including healthcare students, was rather good among respondents, this knowledge does not correspond with compliance with those recommendations. Despite the fact that more than $3 / 4$ of HCWs know the recommendations, and that the influenza vaccination rate among this group is higher than in the general population, it remains at an unsatisfactory low level of nearly $10-14 \%$, depending on the epidemiological season.

The vaccination rate among HCWs in Poland was estimated to be about $6.4 \%$ in the $2007-2008$ seasons [9]. Many different factors can influence the decision of vaccination. The influenza vaccination coverage among HCWs varies according to a type of job, for instance, doctors vaccinate more frequently than nurses [3]. A study conducted in Warsaw showed that 22.3\% of doctors vaccinate regularly against seasonal influenza, while in nurses this rate was lower - about $10.6 \%$ [10]. Similarly, a German study confirmed this observation, in which significantly more physicians than nurses felt at 
increased risk for influenza, and influenza vaccine uptake among physicians was higher compared to nurses [11]. Other findings also indicate existing differences according to the medical profession, with a significantly higher vaccination rate among physicians than nurses or pharmacists [12]. Other factors which contribute to immunization against seasonal influenza are: type of specialization, with the highest vaccination rate among paediatricians and general practitioners, and the lowest among surgeons, and workplace - hospital or ambulatory [3].

The main reasons for being vaccinated were contact with patients and avoiding flu-related complications. Machowicz et al. showed that the most important reasons for immunization among medical students were to protect from influenza and the fear of disease consequences [13]. Correspondingly, in a Greek study, the main reason for vaccination was selfprotection (75.9\%) [14], and in Iran, where the most common reason for flu vaccination uptake was a belief that the nature of healthcare work renders medical personnel and students more susceptible to influenza infection (73\%) [15].

Despite rather good knowledge of recommendations, HCWs generally do not vaccinate, with reasons for nonvaccination were mainly lack of time, costs, and the fact that HCWs are not aware of the importance of influenza vaccination, since they think that influenza immunization is unnecessary or ineffective. Similarly, a study conducted by Zielonka et al. showed that $55 \%$ of nurses, $33 \%$ of doctors, and $29 \%$ of medical students were not aware of necessity of immunization [10]. The same study revealed that lack of time or laziness as reasons for non-immunization were indicated by $24 \%$ and $17 \%$ doctors, and $37 \%$ and $30 \%$ medical students, respectively [10]. Compared with other countries, the main reasons for non-vaccination seem to be similar to those which dominate in Poland; for instance, in France, 37\% of medical students indicated laziness as a reason for not being immunized, and 24\% chose lack of time [13].

It is worth mentioning that more than a half of the HCWs had contact with patients while having influenzalike symptoms. This situation has been observed in several previous studies, which reported that three out of four doctors admitted that they had been working and taking care of patients even when they had symptoms of infection of the upper respiratory tract [3]. Although the tendency of healthcare workers to continue to work despite being ill is undesirable, it should be remembered that the influenza virus can also be transmitted to patients by asymptomatic medical personnel; therefore, staying at home while manifesting infection is not the most effective way of prevention and cannot replace vaccines.

The results presented above, in combination with data adduced in the discussion, show that there is a constant need for promoting influenza vaccination among HCWs, and different activities are required to achieve success in that field. Changing the attitude towards influenza vaccination is a great challenge for the education of future HCWs. According to the literature, many different directions are suggested, among which knowledge of high-risk groups and possible influenza-related complications seem to be crucial. This depends mainly on education about the safety and effectiveness of vaccines, students' familiarization with the purpose of vaccination in health care settings, that is, protection of patients from nosocomial spread of influenza, as well as the ethical responsibility of present and future
HCWs. On the other hand, solely theoretical knowledge is insufficient, and does not correspond with the immunization rate in practice.

However, the role of professors, academic teachers, and medical professionals, including occupational health workers, is very important and cannot be underestimated, especially in Poland, where recommended vaccination may be perceived by the label of less important in comparison to obligatory vaccination. What is more, false, dismissive opinions and misconceptions about influenza and influenza vaccination presented in the media should be verified and improved by education, together with the good example of teaching staff and their attitude towards influenza vaccination. Facilitation of easy access to influenza vaccination is another option for elevating the flu immunization uptake. Due to the financial aspects, which may be a limitation, medical universities and hospitals might provide flu vaccines, partially paid or free of charge, for their HCWs and students.

A limitation of this study is the relatively small number of participants. Further studies are necessary to assess the attitude of HCWs to preventive vaccinations. Moreover, the study was conducted before the outbreak of the Coronavirus (COVID 19) pandemic; therefore compliance could have changed during the pandemic.

\section{CONCLUSIONS}

The problem of insufficient influenza vaccination coverage among HCWs requires a broad and complex approach. Increasing knowledge about influenza vaccination should be combined with shaping positive attitudes towards, as well as minimizing perceptual, financial, or organizational barriers. In our opinion, it is also a challenge for occupational health professionals to improve the coverage of vaccination as a part of health promotion and prevention.

\section{REFERENCES}

1. Rizzo C, Rezza G, Ricciardi W. Strategies in recommending influenza vaccination in Europe and US. Hum Vaccin Immunother. 2018 Mar 4; 14(3): 693-698. doi: 10.1080/21645515.2017.1367463

2. Program szczepień ochronnych na rok 2019. Załącznik do komunikatu Głównego Inspektora Sanitarnego z 25 października 2018. [Program for Immunization for year 2019. Annex to the communication of Chief Sanitary Inspector of October 25, 2018, item 104]. Polish.

3. Working Group on Influenza. [Influenza vaccination among healthcare professionals in Poland - the presence and perspectives]. Warszawa: Institute of Health Education Foundation Halina Osińska; 2013. p. 3-15. Polish.

4. Monograph on the Internet: Grypa i jej koszty. Wstępne studium w projekcie dotyczącym wypracowania rozwiązania na poziomie narodowym umożliwiającego istotne zwiększenie wyszczepialności przeciw grypie sezonowej w Polsce. [Seasonal influenza and its costs. Preliminary study in a project to develop a solution at the national level that would allow a significant increase in seasonal influenza vaccinations in Poland]. http://opzg.cn-panel.pl/resources/dokumenty/ dla-pracodawcow/Grypa-i-jej-koszty-w-Polsce.pdf (access: 28.06.2021).

5. Poland GA, Pritish T, Jacobson RM. Requiring influenza vaccination for health care workers: seven truths we must accept. Vaccine. 2005; 23: 2251-2255. doi: 10.1016/j.vaccine.2005.01.043

6. Gołębiak I, Pulkowska-Nowocień A, Topczewska-Cabanek A, et al. [Knowledge, perception and coverage rates regarding influenza vaccination among nursing staff]. Family Medicine \& Primary Care Review. 2015; 17(1): 15-18. Polish.

7. Brydak LB. Skutki zdrowotne i ekonomiczne zakażeń grypą w aspekcie zdrowia publicznego. [Health and economic impacts of influenza 
infections in the context of public health]. Polski Przegląd Nauk o Zdrowiu. 2016; 4(49): 401-407. Polish. https://doi.org/10.20883/ ppnoz.2016.27

8. Centers for Disease Control and Prevention. Recommended Vaccines for Healthcare Workers. https://www.cdc.gov/vaccines/adults/rec-vac/ hcw.html (access: 28.06.2021).

9. Roży A, Jaguś P, Chorostowska-Wynimko J. [Virus infections of the respiratory system in the occupational environment of health care employees]. Bezpieczeństwo Pracy: nauka i praktyka. 2014; 4: 27-29. Polish.

10.Zielonka TM, Lesiński J, Życińska K, et al. [Vaccination against influenza in medical staff of Warsaw university hospitals and in students of Warsaw Medical University]. Med Pr. 2009; 60(5): 369-376. Polish.

11. Leitmeyer K, Buchholz U, Kramer M, et al. Influenza vaccination in German health care workers: Effects and findings after two rounds of a nationwide awareness campaign. Vaccine. 2006; 24: 7003-7008. https://doi.org/10.1016/j.vaccine.2006.04.040

12. Abramson $\mathrm{ZH}$, Levi O. Influenza vaccination among primary healthcare workers. Vaccine. 2008;26:2482-2489. doi: 10.1016/j.vaccine.2008.03.011

13. Machowicz R, Wyszomirski T, Ciechańska J, et al. Knowledge, attitudes, and influenza vaccination of medical students in Warsaw, Strasbourg, and Teheran. Eur J Med Res. 2010; 15(2): 235-240. doi: 10.1186/2047-783x-15-s2-235

14. Dedoukou X, Nikolopoulos G, Maragos A, et al. Attitudes towards vaccination against seasonal influenza of health-care workers in primary health-care settings in Greece. Vaccine. 2010; 28: 5931-5933. doi: 10.1016/j.vaccine.2010.06.108

15. Askarian M, Khazaeipour Z, McLaws ML. Influenza vaccination uptake among students and clinical staff of a university in Iran. IJID. 2009; 13: 476-482. doi: 10.1016/j.ijid.2008.09.013 